\title{
Methanolic and Aqueous Extracts of Corn Silk as Corrosion Inhibitor for Mild Steel in Hydrochloric Acid at Different Temperatures
}

\section{${ }^{1}$ AYAH E, *110RUBITE - OKOROSAYE K, ${ }^{1}$ JAMES AO}

\author{
Department of Pure and Industrial Chemistry, \\ University of Port Harcourt, P.M.B.5323, \\ Port Harcourt, Nigeria. Rivers State \\ Email: kaineorubite@yahoo.com
}

\begin{abstract}
This research work presents a study on the methanolic and aqueous extracts of corn silk for their corrosion inhibitive effect on mild steel in $0.5 \mathrm{M} \mathrm{HCl}$ media at $303 \mathrm{~K}, 313 \mathrm{~K}$ and $323 \mathrm{~K}$ using the weight loss method. Various concentrations of Corn Silk Methanolic Extract (CSME) and Corn Silk Aqueous Extract (CSAE) $(0.1 \mathrm{w} / \mathrm{v}, 0.2 \mathrm{w} / \mathrm{v}, 0.3 \mathrm{w} / \mathrm{v}, 0.4 \mathrm{w} / \mathrm{v}$ and $0.5 \mathrm{w} / \mathrm{v})$ were prepared from the shadow-dried corn silk. Inhibition efficiency of $95.07 \%, 90.91 \%, 83.40 \%$; and $79.43 \%, 72.55 \%, 66.30 \%$ was obtained respectively for CSME and $\mathrm{CSAE}$ at $303 \mathrm{~K}, 313 \mathrm{~K}$ and $323 \mathrm{~K}$ for the highest concentration of extracts $(0.5 \mathrm{w} / \mathrm{v})$. The Inhibition efficiency increased with increase in concentration of the extracts and decreased as temperature increased. The results obtained from both extracts were compared and it showed that the methanolic extract was a better inhibitor than the aqueous extract. From this present work, both extracts was shown to be most effective at $303 \mathrm{~K}$ than at $313 \mathrm{~K}$ and $323 \mathrm{~K}$. It was observed that both extracts inhibited the corrosion of mild steel in acidic media through physical adsorption by forming a barrier on the surface of the metal. Data obtained obeyed Langmuir adsorption isotherm. The Kinetic study of the process proposed a first order reaction type. The usefulness of a waste material as corrosion inhibitor is once more reported.
\end{abstract}

DOI: https://dx.doi.org/10.4314/jasem.v22i3.26

Copyright: Copyright (C) 2018 Ayah et al. This is an open access article distributed under the Creative Commons Attribution License (CCL), which permits unrestricted use, distribution, and reproduction in any medium, provided the original work is properly cited.

Dates: Received: 20March 2018; Revised: 22 March: 2018; Accepted: 23 March 2018

Keywords:inhibition efficiency, corn silk, methanolic extract, first order, adsorption isotherm.

As defined by Popoola et al., (2013) corrosion is the deterioration of metal due to its relationship with the enclosing environment. It is the gradual return of metal to its natural state (Natty, 2010). Most industries depend heavily on the use of metals and alloys in industrial application; and the protection of these against corrosion is one unending and difficult task for such industries. Metallic corrosion is of practical concern because of the increased use of strong acid attacking equipment surface during Industrial applications (acid cleaning, pickling, descaling, oil well acidizing operations, and in the refining of crude oil) (Ostovari et al., 2009). This process however, causes damage to the metal in the long run and thus has to be prevented or controlled. Some ways of prevention include upgrading materials, process control and chemical inhibition (Dudukcu et al., 2004). Amongst these, corrosion inhibitors (De Souza and Spinelli, 2009) are seen as the best preventive method. Corrosion inhibitors are chemicals either synthetic or

natural which, when added in small amounts to an environment, decrease the rate of attack by the environment on metals. The term "green inhibitor" refers to inhibitors that have low toxicity, eco- friendliness, and good efficiency and are biocompatible with nature. Inhibitors like plant extracts apparently possess such biocompatibility properties due to their biological origin (Koch et al., 2002). The antioxidant property of the plant material is due to the presence of many active phytochemicals including vitamins, flavonoids, tereponoids, carotenoids, cumarins, lignin, plant sterol etc which are believed to be in different parts of the plants e.g. fruits, leaves, stem, roots etc as reported by different researches and some economic plants have also been reported (Rehan 2003). This forms the basis of utilization of plant materials that are of less economic importance, or regarded as waste material as these would not only find use for these but also make the environment greener. This is the basis of using corn silk in this research work.

Corn silks are a bundle of silky, long and yellowish strands on top of the corn fruit. Corn is a seasonal plant which is obtainable within the summer period in Nigeria. It is a common practice to see sellers of cooked and roasted corn in vendors at the East-West road junction of the University of Port-Harcourt. The corn silk used was obtained from these sellers. When 
matured corn plant is harvested, corn silks are discarded while the fruit is prepared for meals. However some traditional use of corn silk has been reported (Maksimovic 2003). The phytochemical composition of corn silk contains flavonoids, terpenoids and phenolic compounds which are effective as anti-oxidants and antibacterial (Tianet al 2013). These compounds generally have conjugated aromatic structure, long aliphatic chains such as $\mathrm{N}, \mathrm{S}$, and $\mathrm{O}$ heteroatom with free electro pairs that are available to bond with metal surface (Paulina Arellanes- Lozada et al., 2015). Recently, Orubite and Ngobiri (2017) investigated the effectiveness of corn silk water extract (CSWE) as corrosion inhibitor of mild steel in $0.5 \mathrm{M} \mathrm{HCl}$ solution at $303 \mathrm{~K}, 313 \mathrm{~K}$ and $323 \mathrm{~K}$. The use of methanolic extract of corn silk as corrosion inhibitor has not been reported. Hence, the aim of this work is to compare the effectiveness of corn silk methanolic extract (CSME) with corn silk aqueous extract (CSAE) as corrosion inhibitor for mild steel in $0.5 \mathrm{M} \mathrm{HCl}$ medium at $303 \mathrm{~K}$, $313 \mathrm{~K}$, and $323 \mathrm{~K}$.

\section{MATERIALS AND METHODS}

Preparation of metal coupons: The sheets of mild steel were obtained locally with thickness $1.00 \mathrm{~mm}$ and purity $98.76 \%$. In order to conduct the weight loss experiment the metals were mechanically pressed-cut into $2 \mathrm{~cm}$ by $5 \mathrm{~cm}$ coupons with average weight of the coupon as $4.3911 \mathrm{~g}-7.2685 \mathrm{~g}$. The mild steel coupons were first polished by scrubbing with sandpaper, degreased by immersion in absolute ethanol and drying in acetone. It was immersed in a solution of $\mathrm{HCl}$ with acid to water ratio of 1 to 4 for 30 minutes at room temperature and then rinsed with distilled water. Later dried with clean cloth and finally stored in desiccators prior to the commencement of the experiment. The initial weight of the coupons was taken using an analytical weighing balance. Each weight was an average of three replicate measurements and all labelled.

Corrosion environment used:The environment utilized in this study is $0.5 \mathrm{M} \mathrm{HCl}$ of analar grade.

Acid preparation and calculations: Acid solution was prepared using this equation:

Volume of $\mathrm{HCl}=$

Molecular weight X Required molar Concentration X L X100

Equ. 1 $\%$ Assay $X$ specific gravity

Where: Molecular weight $=36.5$; Required molar Concentration $=0.5 \mathrm{M} ; \mathrm{L}=1$ Litre; $\%$ Assay $=37 \%$; Specific gravity of $\mathrm{HCl}=1.18 \mathrm{~g} / \mathrm{ml}$
From the result obtained after calculation, approximately $41.8 \mathrm{~cm} 3$ of the stock was made up to $1000 \mathrm{~cm} 3$ in a 1 Litre standard flask to obtain the $0.5 \mathrm{M}$ concentration of hydrochloric acid solution.

Preparation of methanolic and aqueous extracts of corn silk: In obtaining the extracts, fresh corn silks was rinsed with deionised water to remove sand and dirt, and dried under a shadow. The shadow method was done to make sure that the natural constituent of the silk was not denatured. The dried corn silk was pulverized using a grinding machine to obtain a very fine powder.

The methanolic extract was obtained by using a Soxhlet extractor and methanol as the solvent. About136.9g of the ground corn silk was used. The extract was concentrated and some dry component gotten by evaporation to dryness.

The aqueous extract was obtained by dissolving $184.6 \mathrm{~g}$ fine powder of corn silk in 2 liters of deionised water for 48 hours. The mixture was filtered with a Whatman filter paper to separate filtrate from residue. This process of filtration was done continuously until a clear solution was obtained and then evaporated to dryness.

Then both dried extracts was scrapped out and stored in a sample bottle. Five different concentrations expressed in terms of $\%(\mathrm{w} / \mathrm{v})$ were prepared as $0.1 \mathrm{~g} / 500 \mathrm{ml}$, $0.2 \mathrm{~g} / 500 \mathrm{ml}, \quad 0.3 \mathrm{~g} / 500 \mathrm{ml}, \quad 0.4 \mathrm{~g} / 500 \mathrm{ml}, \quad$ and $0.5 \mathrm{~g} / 500 \mathrm{mlf}$ or both extracts with $0.5 \mathrm{M} \mathrm{HCl}$ acid solution. A fifth flask contained only $0.5 \mathrm{M} \mathrm{HCl}$ (blank).

Weight Loss Measurement / Gravimetric Experiment: Six previously weighed coupons were plunged into the beakers containing the various volumes of extract and $0.5 \mathrm{M} \mathrm{HCl}$ only (blank) as previously explained. The coupons were retrieved after every 24 hours. The duration for the experiment was 7 days; the coupon was then removed, washed, dried and weighed. The weight loss of the metal, inhibition efficiency $\left(\% \mathrm{I}_{\mathrm{E}}\right)$ of the inhibitor, the degree of surface coverage $(\theta)$ was calculated using the equations below:

The difference in weight of the coupon was taken as the weight loss using the formulae;

$$
\Delta \mathrm{w}=w f-w i \quad \text { Eq. } 2
$$

Where $\Delta \mathrm{w}=$ weight loss $(\mathrm{gms}) ; w f=$ final weight of coupons; $w i ́=$ initial weight of coupons

This experiment was repeated at higher temperatures of $313 \mathrm{~K}$ and $323 \mathrm{~K}$ in a thermostatic water bath.

As described by (Ebenso et al., 2004; Omotosho et al., 2012), the percentage inhibitor efficiency $\left(\% \mathrm{I}_{\mathrm{E}}\right)$ was obtained from the relationship in equation 3 below: 
Inhibition Efficiency $(\mathrm{IE} \%)=\frac{\Delta \mathrm{WB}-\Delta \mathrm{Wi}}{\Delta \mathrm{WB}} \times 100 \mathrm{Eq} .3$ Where, $\Delta \mathrm{W}_{\mathrm{B}}$ and $\Delta \mathrm{W}_{\mathrm{i}}$ are the weight loss data of the metal coupons in the absence (blank) and presence of an inhibitor respectively.

The Surface coverage $(\theta)$ was obtained from Equation 4 below:

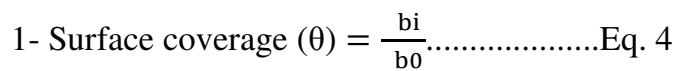

Where $b_{i}=$ weight loss inhibition; $b_{0}=$ uninhibited corrosion rate or weight loss blank

\section{RESULTS AND DISCUSSION}

Variation of Weight Loss with Time for Mild Steel Coupons in $0.5 \mathrm{M} \mathrm{HCl}$ solution containing different concentrationsof inhibitor.
Weight loss measurement is the simplest and most versatile method used to measure the corrosion rate of the metal. Afolabiet al (2014) mentioned that it is ideally as good as other techniques for corrosion evaluation of metals in an immersion test. Weight loss measurement requires no sophisticated instruments to obtain a result and is applicable to all corrosive environments. The method is commonly used as a calibration standard for other means of corrosion monitoring. In this work weight loss of mild steel coupons immersed in $0.5 \mathrm{M} \mathrm{HCl}$ was periodically measured to ascertain the corrosion rate in the acidic medium. The blank as shown in Fig 1 and 2 confirms that the mild steel coupons actually corrode in the acid medium.

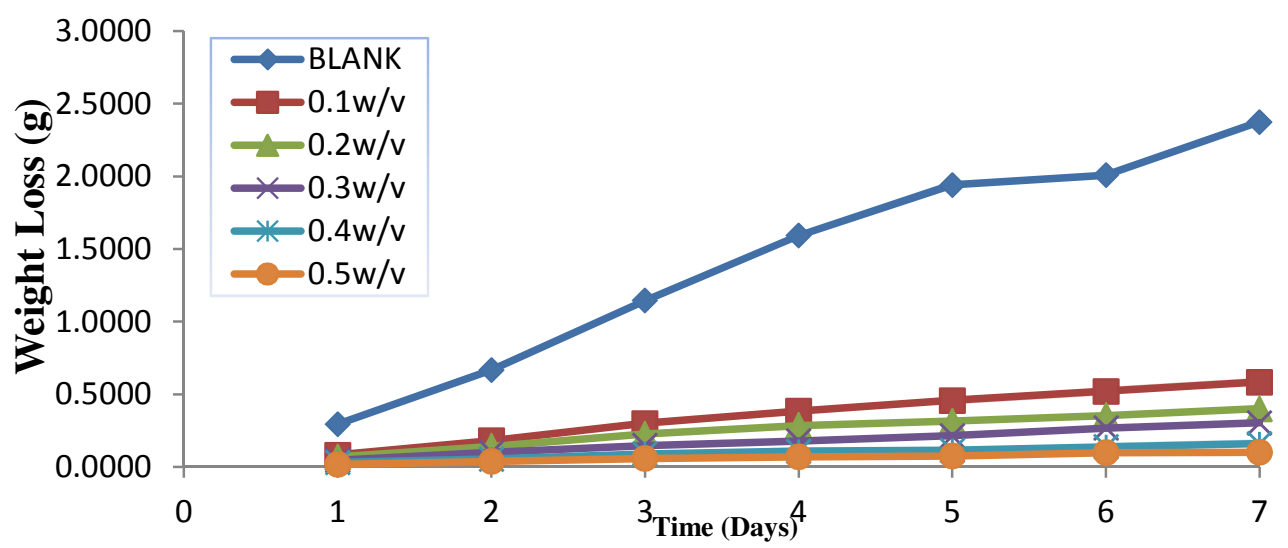

Fig 1 Variation of Weight Loss with Time for Mild Steel Coupons in $0.5 \mathrm{M} \mathrm{HCl}$ solution containing different concentrations of CSME at $303 \mathbf{~ K}$

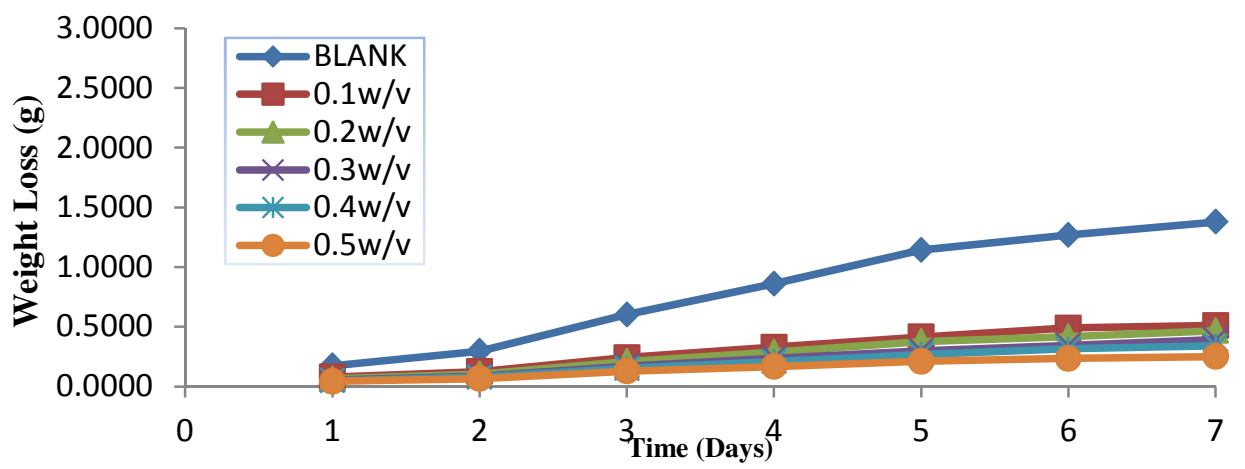

Fig 2 Variation of Weight Loss with Time for Mild Steel Coupons in $0.5 \mathrm{M} \mathrm{HCl}$ solution containing different concentrations of CSAE at $303 \mathbf{~ K}$

The obvious difference in the weight loss of the metal coupons on the blank (absence of extracts) and the addition of extracts reveals that the extracts remarkably reduced the corrosion of the mild steel. As evident in the graphs, even the lowest concentration of $0.1 \mathrm{~g} / 500 \mathrm{ml} \mathrm{CSME}$ and CSAE recorded a weight loss value lower than that of the blank. This pattern was also observed by previous authors (James and Akaranta, 2014; Orubite and Ngobiri, 2017).

Effect of temperature on percentage inhibition efficiency: The corrosion of mild steel in $0.5 \mathrm{M} \mathrm{HCl}$ was studied at three temperatures: 303K, 313K and 323K. Results are shown in Figs. 3 and 4. 


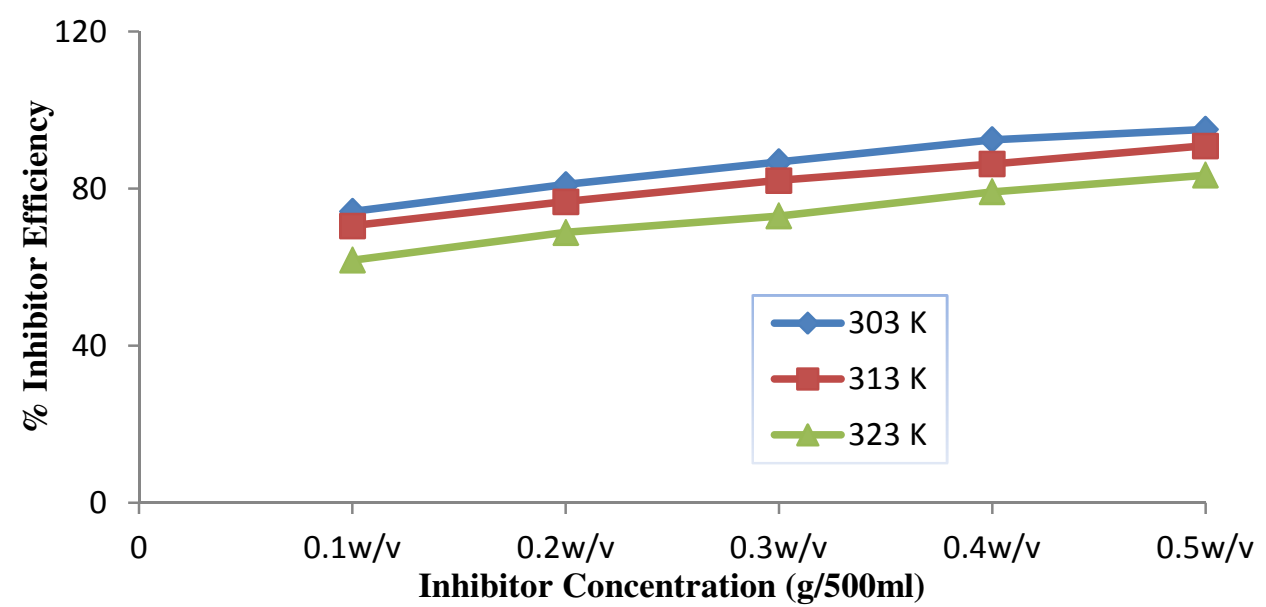

Fig 3 Average Percentage Inhibition Efficiency (\%IE) of different concentrations of CSMEfor the Inhibition of Mild Steel corrosion in 0.5 M $\mathrm{HCl}$ solution at different temperatures

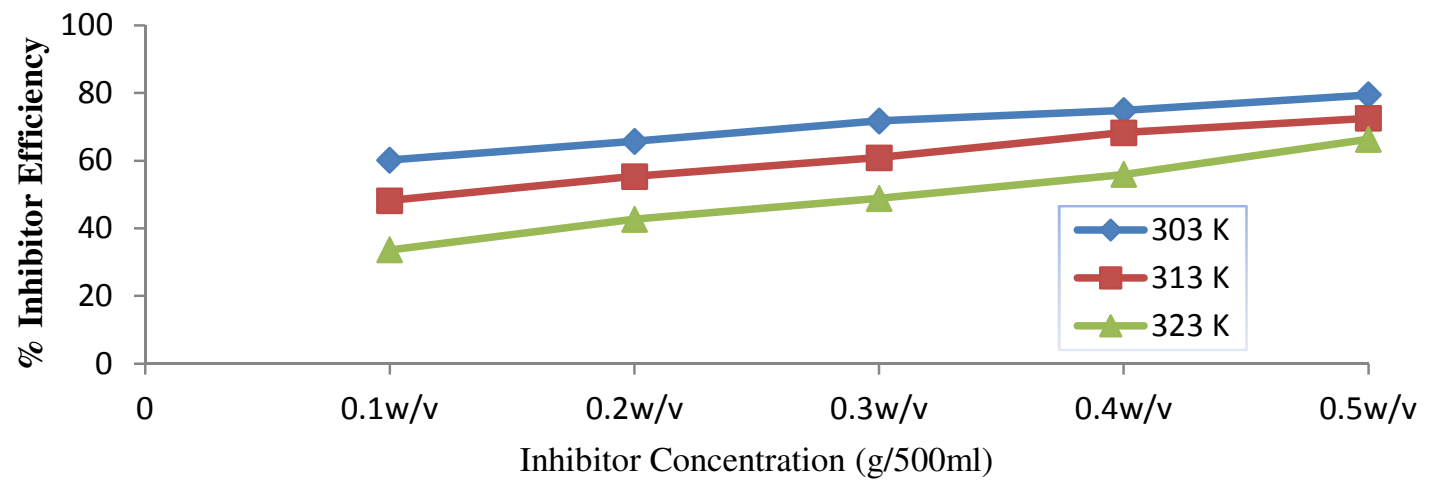

Fig 4 The Average Percentage Inhibition Efficiency (\%IE) of different concentrations of CSAE for the Inhibition of Mild Steel corrosion in $0.5 \mathrm{M} \mathrm{HCl}$ solution at different temperatures

It is obvious from the graphs that as temperature of the reaction system increased from $303 \mathrm{~K}-323 \mathrm{~K}$, the inhibition efficiency decreased from $95.07 \%-83.40 \%$ for CSME and from $79.43 \%-66.30 \%$ for CSAE. The pattern of temperature dependence of the inhibition efficiency is similar to reports by other researchers (Orie, 2015 James and Akaranta 2014 ). Both CSME and CSAE protection of mild steel surface was less efficient at higher temperatures of $313 \mathrm{~K}$ and $323 \mathrm{~K}$. It is well known that temperature increases the rate of most chemical reactions, thus, two reasons can be deduced to explain this inhibition efficiency pattern; according to Singh (2010), at these higher temperatures there was increased rate of dissolution of mild steel and secondly partial desorption of the inhibitor molecules formed on the metal surface. This is suggestive of the fact that both extracts from corn silk adsorbed on the metal surface at different temperatures studied. The decrease in inhibition efficiency was probably due to decreasing strength of adsorption (shifting the adsorption desorption equilibrium toward desorption).

Comparison of the Inhibition Effectiveness of methanolic and aqueous extracts on Mild Steel Corrosion 


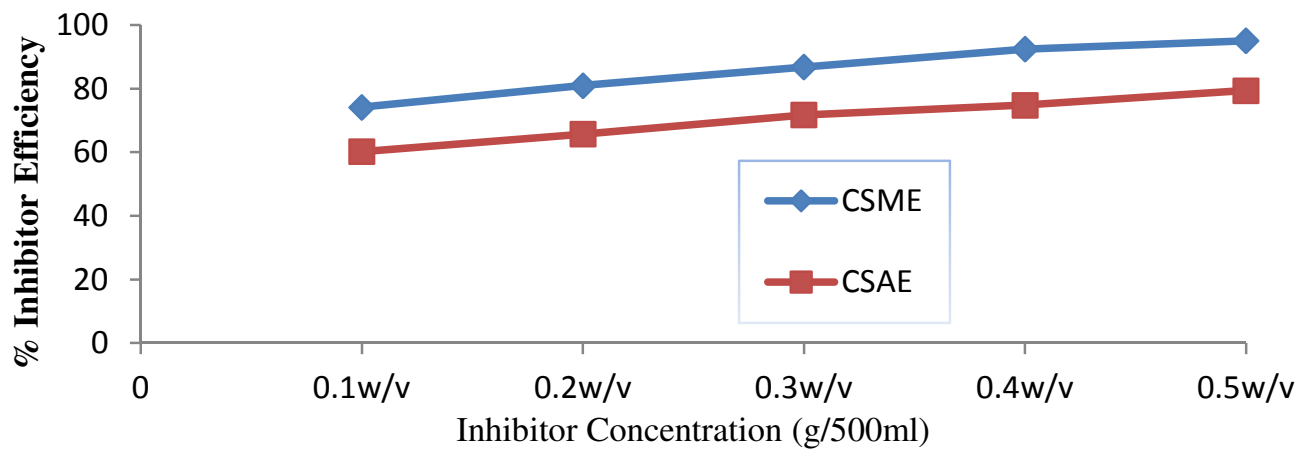

Fig 5:The Average Percentage Inhibition Efficiency (\%IE) of CSMEand CSAE for the Inhibition of Mild Steel corrosion in $0.5 \mathrm{M} \mathrm{HCl}$ solution at $303 \mathrm{~K}$.

Inhibition efficiency is measured to evaluate the effectiveness of an inhibitor. The effectiveness of aqueous extract of corn silk as corrosion inhibitor was reported by Orubite and Ngobiri (2017). The inhibition efficiency of the two extracts was found to be concentration dependent also. As shown in fig. 5, the inhibition efficiencies for the respective inhibitor concentrations of $\mathbf{0 . 5 w} / \mathbf{v}, 0.4 \mathrm{w} / \mathrm{v}, 0.3 \mathrm{w} / \mathrm{v}, 0.2 \mathrm{w} / \mathrm{v}$ and $0.1 \mathrm{w} / \mathrm{v}$ for CSME at $303 \mathrm{~K}$ is in the order $(95.07 \%)>$ $(92.43 \%)>(86.83 \%)>(81.01 \%)>(74.17 \%)$ and for CSAE is observed to be in the order: $(79.43 \%)>$ $(74.80 \%)>(71.72 \%)>(65.73 \%)>(60.19 \%)$ for mild steel corrosion.

Fig. 5 also showsa remarkable difference between inhibition efficiencies of both extracts at the same temperature. CSME inhibited corrosion of mild steel better than CSAE. This may be due to the fact that methanol is an amphiphilic compound(Paulo Cameira da Santos, 2015), consisting of molecules having a polar water soluble group attached to a water-insoluble hydrocarbon chain; the molecules of methanol consists in a single atom of a tetraedric carbon, linked to 3 hydrogen, and an $-\mathrm{OH}$ group. The $-\mathrm{OH}$ group is the polar group, while the 3 hydrogen is the water-insoluble hydrocarbon chain. This amphiphilic ability causes methanol to be able to dissolve and extract both polar molecules and also non-polar ones. Therefore, we can say that the methanol solvent during extraction, extracted all the various chemical groups from the corn silk which would not be soluble and thus not all extracted in the aqueous medium $\left(\mathrm{H}_{2} \mathrm{O}\right)$ but would be readily soluble in methanol (organic solvent).Methanol is also considered a better solvent since it is easier to separate from the extract when finer purification of the compound of interest is to be done (evaporation to dryness), due to its lower boiling point of about $65^{\circ} \mathrm{C}$ when compared to water of $100^{\circ} \mathrm{C}$.

At the higher temperatures of $313 \mathrm{~K}$ and $323 \mathrm{~K}$, the inhibition efficiencies of all the inhibitors were observed to decrease. Thismay be attributed to the fact that increase in temperature decreases the rate of adsorption on metal surface probably due to the weakening of the Vander Waals forces of attraction and constant bombardment of the molecules (Piriya, 2018). The interaction of the energized molecules coupled with the increased rate of desorption of adsorbed species, results in the formation of very weak film coverage which can easily be washed by the corrosive medium, hence, the general decrease in inhibition efficiency at higher temperature. This conforms to the findings of Ekpe et al., 1994; Orie, 2015.

Adsorption Isotherm Analysis: Inhibitor molecules retard the corrosion process by instituting an interaction with the metal surface. Thus inhibition is said to take place when the molecules are adsorbed on the metal surface. Adsorption isotherm gives information on metal-inhibitor interaction (Manimegalai, 2015) and the reaction of metal surface and inhibitor while the surface coverage $(\theta)$ expresses the extent of coverage of inhibitor molecules on metal surface. 


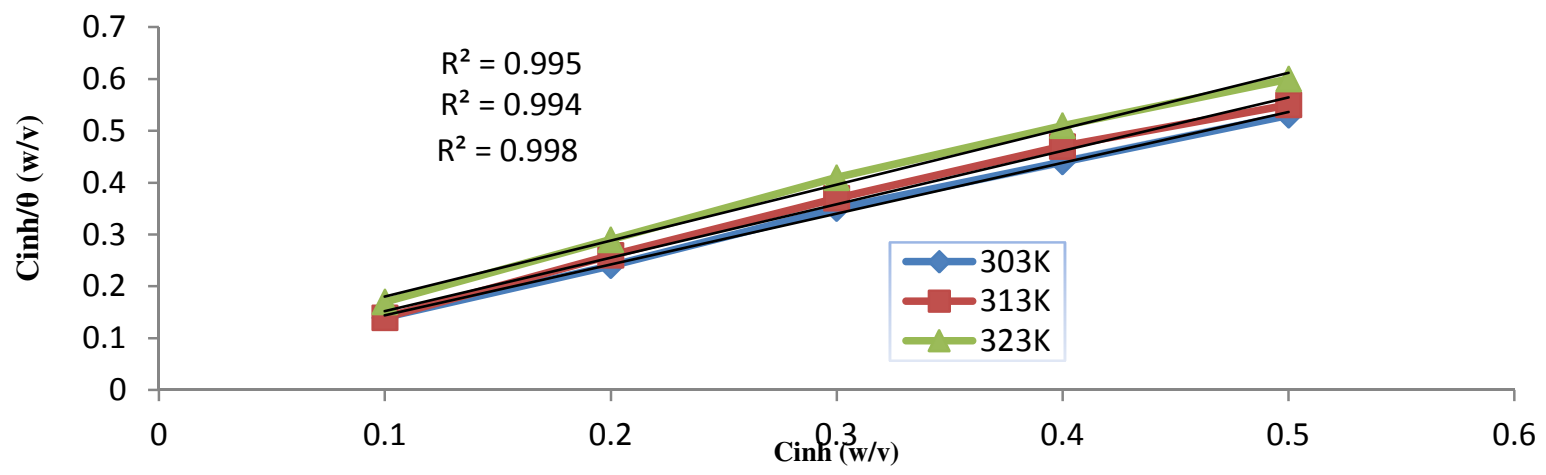

Fig 6 Langmuir Adsorption Isotherm of CSME on Mild Steel in $0.5 \mathrm{M} \mathrm{HCl}$ solution at different temperatures

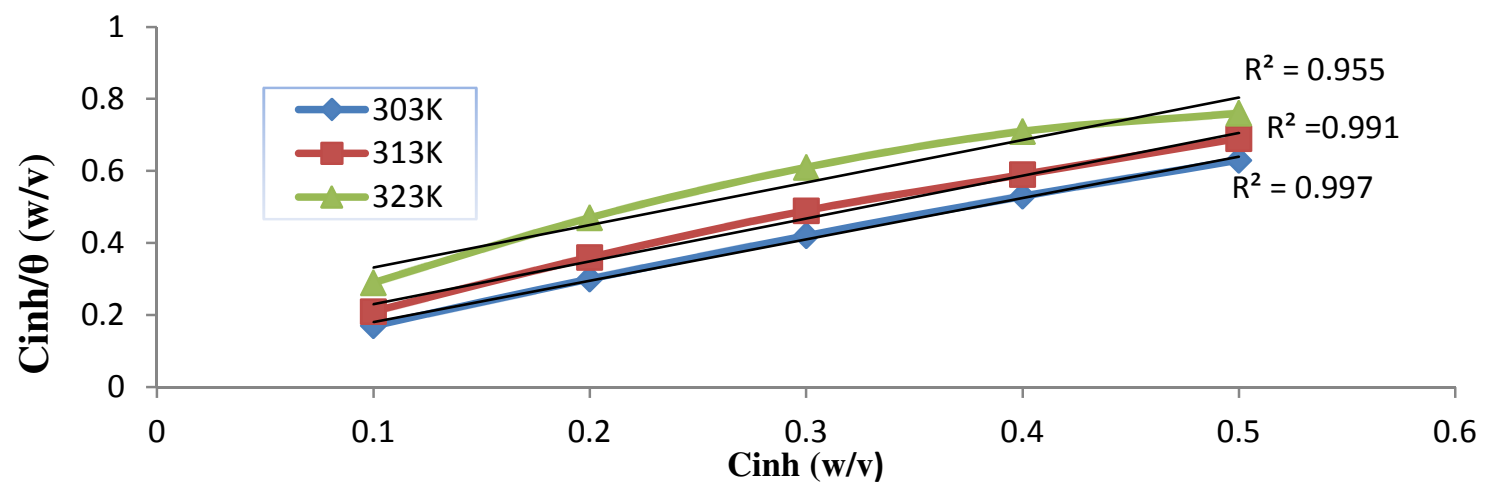

Fig 7:Langmuir adsorption isotherm of CSAE on mild steel in $0.5 \mathrm{M} \mathrm{HCl}$ solution at different temperatures

The relationship between surface coverage and inhibitor molecules (concentration) is portrayed in Langmuir isotherm (Figures 6 and 7) for both CSME and CSAE respectively. A plot of Cinh/ $\theta$ versus $\mathrm{C}$ gave a straight line graph with correlation coefficient values $\left(R^{2}\right)$ almost unity which best explains the metal surface-inhibitor interaction. The straight line relationship indicates that the adsorption of CSME and CSAE on the metal follows Langmuir adsorption isotherm even at higher temperatures. Same pattern was reported by Orubite and Ngobiri (2017).

Kinetics and Thermodynamic Consideration

Table 1: Kinetic data for Mild steel in $0.5 \mathrm{M} \mathrm{HCl}$ containing CSME and CSAE from weight loss Measurements

\begin{tabular}{|c|c|c|c|c|c|}
\hline \multirow[t]{2}{*}{ Extract } & \multirow{2}{*}{$\begin{array}{l}\text { Rate Constant } \\
\qquad \mathrm{k} \\
\left(\text { day }^{-1}\right) \times 10^{-2}\end{array}$} & \multirow[t]{2}{*}{$\begin{array}{l}\text { Half-life } t_{1 / 2} \\
\text { (days) } \times 10^{-1}\end{array}$} & \multicolumn{2}{|c|}{$\begin{array}{l}\text { Average activation Energy Ea } \\
\qquad\left(\mathrm{kJmol}^{-1}\right)\end{array}$} & \multirow[t]{2}{*}{$\% \mathrm{I}_{\mathrm{E}}$} \\
\hline & & & $303 \mathrm{~K}-313 \mathrm{~K}$ & $313 \mathrm{~K}-323 \mathrm{~K}$ & \\
\hline CSME & 0.33 & 21.00 & 78.65 & 58.25 & 95.07 \\
\hline CSAE & 0.68 & 10.19 & 88.56 & 67.82 & 79.43 \\
\hline
\end{tabular}

Table 2:Thermodynamic data for Mild steel in $0.5 \mathrm{M} \mathrm{HCl}$ containing CSME and CSAE from weightloss Measurements

\begin{tabular}{|c|c|c|c|c|}
\hline Extract & Surface Coverage 303K $\theta$ & $\begin{array}{c}\text { Average } \triangle \mathrm{G}^{0} \text { ads } \\
\text { (Free energy of } \\
\text { adsorption) } \\
\left(\mathrm{kJmol}^{-1}\right) \\
\mathrm{n}=9\end{array}$ & $\begin{array}{c}\text { Average } \triangle \mathrm{H}^{0} \text { ads } \\
\text { (Heat of adsorption } \\
\text { (Adsorption Enthalpy)(kjmol }\end{array}$ & $\begin{array}{c}\left.{ }^{-}\right) \\
\text {(Entropy of adsorption) } \\
\text { (j/mol/k) }\end{array}$ \\
\hline CSME & 0.95 & -25.86 & -13.89 & 39.5 \\
\hline CSAE & 0.80 & -15.29 & 1.04 & 53.92 \\
\hline
\end{tabular}

Kinetic consideration of the corrosion reaction:

Chemical kinetics includes investigations of how experimental conditions can influence the rate of a chemical reaction. The rate constant gives a direct measure of the relative corrosion rate; how fast or slow the reaction is, generally a small value equates a slow reaction while a large means reaction is rapid. For this study the rate constant was calculated using equation below 
$\mathrm{k}=\frac{2.303}{T} \log \frac{w i}{w f} \quad \ldots \ldots \ldots \ldots \ldots \ldots \ldots . . . . \ldots q u .5$

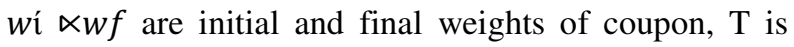
time.

Calculated values of rate constants, $\mathrm{k}$, half - life, $\mathrm{t}_{1 / 2}$, activation energy, Ea for mild steel corrosion in $0.5 \mathrm{MHCl}$, with inhibitors CSME and CSAE are presented in Table 1. The pattern of the values obtained was highest for the smallest concentration of the individual extracts $0.1 \mathrm{~g} / 500 \mathrm{ml}$ and lowest for the highest concentration of both extracts at $0.5 \mathrm{~g} / 500 \mathrm{ml}$, and its dependence on temperature is similar to that already described for inhibition efficiency. The kinetics of corrosion process acquire the character of a diffusion process, in which at higher temperature, the quantity of inhibitor molecules present at the metal surface is lower than at lower temperatures. This assertion is strongly supported by Ebenso et al (2004).

The rate constant, $\mathrm{k}$ generally decreased while the half-life, $t_{1 / 2}$ increased with increase in concentration of the inhibitors.

Thermodynamic data obtained and their significance:The free energies of adsorption $\Delta \mathrm{G}^{0}$ ads were calculated using the Bockris- Swinkels equation written as:

$$
\Delta G^{0}=\frac{-2.303 R T \log \left[55.4 \theta\{\theta+(1-\theta) n\}^{n-1}\right]}{\operatorname{Cinh}(1-\theta)^{n}} \quad .6
$$

Where Cinh $=$ Concentration of inhibitor in the bulk of the solution; $n=$ the size factor $n=9$, for flat adsorption of additive on the metal surface; $n=3$, for perpendicular direction to the surface $55.4=$ molar concentration of water in the solution, $\boldsymbol{\theta}=$ surface coverage,

$\mathrm{R}=$ universal gas constant; $\mathrm{T}=$ absolute temperature.

Generally, value of $\Delta \mathrm{G}^{0}$ ads around $-25 \mathrm{KJ} / \mathrm{mol}$ or lower are consistent with the electrostatic interaction between the charged molecule and the metal surface (physical adsorption), those around $-40 \mathrm{KJ} / \mathrm{mol}$ or higher involve charge sharing or transfer from organic molecule to the surface to form a coordinate type of bond (Loto and Popoola, 2012). It was observed that for CSME and CSAE, the $\mathrm{G}^{\mathrm{O}}$ ads values are all negative and range in an order of increasing temperature of $303 \mathrm{~K}, 313 \mathrm{~K}$ and $323 \mathrm{~K}$ as $(-18.55$ to $36.81)(-18.06$ to -28.24$)(-15.96$ to -20.31$) \mathrm{kJmol}-1]$ for CSME and[(-14.51 to -17.20$),(-12.55$ to -14.59$)$, (10.48 to -12.72 ) $\mathrm{kJmol}-1$; ] for CSAE respectively. These values show the reaction follows a physical adsorption (range of $-25 \mathrm{KJ} / \mathrm{mol}$ ). The negativity of the $\Delta \mathrm{G}^{\mathrm{O}}$ ads values indicate that adsorption and inhibition efficiency decreases with rise in temperature which agrees with findings of Orubite and Ngobiri 2017. It also implies that the adsorption of the inhibitor molecules on mild steel is spontaneous. The thermodynamic functions of $\Delta \mathrm{H}^{\mathrm{O}}$ and $\Delta \mathrm{S}^{\mathrm{O}}$ for corrosion inhibited solutions were obtained from the following equations.

$$
\begin{aligned}
\Delta H^{\mathrm{O}} & =\Delta \mathrm{Ea}-\mathrm{R} \cdot \mathrm{T}(\mathrm{7}) \\
\Delta \mathrm{G}^{\mathrm{O}} & =\Delta \mathrm{H}^{\mathrm{O}}-\mathrm{T} \Delta \mathrm{S}^{\mathrm{O}}
\end{aligned}
$$

The small values of $\Delta \mathrm{H}^{\mathrm{O}}$ in presence of inhibitor are typical of a physisorption process. $\Delta \mathrm{S}^{\mathrm{O}}$ values were around $+45 \mathrm{~J} / \mathrm{mol} / \mathrm{K}$ and the sign indicates increase in system disorder in the transition state due to interfacial processes as well as mass transfer in bulk solution and at the metallic surface. Shalabi et al., (2014) had an almost similar report with a proposed physisorption mechanism.

Conclusion: The aqueous and methanolic extracts of corn silk as inhibitors retarded the acid corrosion of mild steel in $0.5 \mathrm{M} \mathrm{HCl}$ solution to an appreciable extent in all the temperatures studied $(303,313,323 \mathrm{~K}$. Inhibition efficiency $\left(\% \mathrm{I}_{\mathrm{E}}\right)$ remarkably increased with increase in extracts (inhibitor) concentration and decreased with increase in temperature. The values of $\Delta \mathrm{G}_{\text {ads }}$, obtained between $303 \mathrm{~K}, 313 \mathrm{~K}$ and $323 \mathrm{~K}$ were all negative indicating that the inhibitors are strongly adsorbed on mild steel surfaces and that the adsorption process is spontaneous. The adsorption characteristics of CSAE and CSME also fitted into Langmuir adsorption isotherm thus following a first order kinetics. The inhibition effectiveness of both extracts has been attributed to the presence of the hetero atoms $\mathrm{N}, \mathrm{O}$ and $\mathrm{S}$ present in its phytochemical composition. The CSME exhibited greater inhibition efficiencies (95.07\%) than the CSAE (79.43) under the same conditions. This has been attributed to the amphiphilicproperties of methanolwhich was able to dissolve and extract both polar molecules and non-polar constituents of the corn silk. In contrast, water, a polar solvent extracted only the polar constituents of the corn silk. It can be concluded therefore that the methanolic extract of corn silk is a better inhibitjon in this study.

\section{REFERENCES}

Afolabi A.S, Muhirwa1 A.C, Abdulkareem A.S and Muzenda, E ( 2014); Weight Loss and Microstructural Studies of Stressed Mild Steel in Apple JuiceInt. J. Electrochem. Sci., 9 (2014) 5895 - 5906

De Souza, F. S., Spinelli, A., (2009). Caffeic acid as a green corrosion inhibitor for mild steel.

Corrosion Science 51 (3), 642 - 649 
Dudukcu, M., Yazici, B., Erbil, M., (2004) Mater.Chem. Phys. 87, 138. Economic Effects of Metallic Corrosion in the United States, 1978a, NBS Special Publication 511-1, SD Stock No. SN003-003-01926-7.

Ebenso, E. E., Ibok, U. J., Ekpe, U. J., Umoren, S., Jackson, E., Abiola, O. K., Oforka, N.C.,

Martinez, S.(2004). Corrosion inhibition studies of some plant extracts on aluminium in acidic medium.Transactions of the SAEST (Society for advancement of Electrochemical Scienceand Technology), 39 (4), 117-123.

Ekpe, U. J., Ebenso, E. E., and Ibok, U. J. (1994).Inhibitory action of Azadirachtaindica leaves extract on the corrosion of mild steel in $\mathrm{H}_{2} \mathrm{SO}_{4}$.Journal of West African Science association, 37, 13.

James A. O (2006). Inhibition of corrosion of Aluminium and mild steel in hydrochloric and sulphuric acid solutions by pyridoxal hydrochloride, pyridxoxol hydrochloride and 2benzoyl pyridine.

James, A.O. and Akaranta, O. (2014). Kinetic studies of the corrosion inhibition of mild steel in $2 \mathrm{M}$ sulphuric acid solution using red peanut skin extract as inhibitor. International Journal of Materials, Methods and Technologies; 2(3): 1 - 9 .

Koch, G. H., Brongers, M. P. H., Thompson, N. G., Virmani, Y. P., \& Payer, J. H. (2002).

Corrosion Costs and Preventive Strategies in the United States. NACE Intl PHWA-RD-01-156

Loto R. T, Loto C. A., Popoola A. P. I., Effect of Aminobenzene Concentrations on the corrosion inhibition of mild steel in sulphuric acid. Int. J. Electrochem. Science, 7: 7016-7032.2012.

Manimegalai, S; Manjula , P; (2015). Thermodynamic and Adsorption studies for corrosion of mild steel in aqueous media by sargasamswartzii( Brown algae ). Journal of material Environmentalscience, 6 (6), 1629-1637.

Maksimovic, Z. A.; Kovačević, N. (2003).Preliminary assay on the antioxidative activity of Maydis stigma extracts. Fitoterapia, 74, 144-147.

Natty, K. (2010). Corrosion and its Mitigation in the Oil and Gas Industry; Leonardo Journal of Science, 23(6): $12,19$.

Okorosaye - Orubite, K; Ngobiri N. C (2017). Corn Silk as Corrosion Inhibitor for Mild Steel in $0.1 \mathrm{M}$

$\mathrm{HCl}$ Medium. IOSR Journal of Applied Chemistry, 10 (3) 2278-5736 DOI: 10.9790/5736-1003015160
Omotosho, O.A., Ajayi, O.O., Ajanaku, K.O., Ifepe, V.O. (2012). Environment Induced Failure of Mild Steel in $2 \mathrm{M}$ Sulphuric Acid using Chromolaenaodorata. Journal of Materials and Environmental Science, 3 (1), 66-75.

Orie, K. J; Christian M., 2015. The Corrosion Inhibition of Aluminium Metal In 0.5M Sulphuric Acid Using Extract Of Breadfruit Peels. International Research Journal of Engineering and Technology (IRJET) 2 (8) 2395-0072

Ostovari, A., Hoseinieh, S.M., Peikari, M., Shadizadeh, S.R., Hashemi, S.J., 2009. Corrosion inhibitionof mild steel in $1 \mathrm{M} \mathrm{HCl}$ solution by henna extract: a comparative study of the inhibition by henna and its constituents (Lawsone, Gallic acid,a-d-Glucose and Tannic acid). Corros. Sci. 51, 1935-1949.

Paulina Arellanes- Lozada,, Octavio OlivearesXometl, Natalya V. Likhanova, Irina Lijanova,

M. A Ramirez- Garnica, Elsa M . Arce- Estranda. Evaluation of corrosion inhibiting effect of ionic liquid ( $\mathrm{N}$ - dimethyl- $\mathrm{N}$ - di (cocoalkyl) Ammonium methyl sulphate) on API 5L X52 steel in $\mathrm{HCl}$ acid. International journal of electrochemical science 10 (2015) 2776 -2790.

Paulo Cameir dos Santos (2015). https://www.google.com/amps/s/www.researchgate .net/post/Why_is__methanol_generally_ used _as _a _first_solvent_for_extraction _purpose _to look_for_bioactives_in_medicinal_plants/amp PiryaVadhannaB.V.(2018).https://www.quora.com/ why_does_physical_adsorption_decrease_wi the_rise_in_temperature?

Popoola, L.T., Grema, A.S., Latinwo, G.K., Gutti, B., \&Balogun, A.S. (2013). Corrosion

Problems During Oil and Gas Production and its Mitigation. International Journal of Industrial Chemistry, 4(35), 1-15.

Rehan, H. H (2003). Corrosion control by water soluble extracts from leaves of economic plants. Matt.-wiss. U. werks to fftech , 34, 232-237

Shalabi, K., Elewady, G. Y., Habbouba, S., (2014). Gibberellic acid as green corrosion inhibition forcarbon steel in hydrochloric acid solutions. J. Mater. Environ. Sci.

Singh, A., Singh, V. K., Quraishi, M. A., 2010. Effect of fruit extracts of some environmentally benign green corrosion inhibitors on corrosion of mild steel in hydrochloric acid solution. J. Mater. Environ. Sci. 3, 163-174.

Tian, J., Chen, H., Chen, S., Xing, L., Wang, Y.,Wang, J. (2013). Comparative studies of the constituents, antioxidants and anticancer activities of extracts from different varieties of corn silk. Food funct. (4) 1526-1534 